\title{
Fascism and (Transnational) Social Movements: A Reflection on Concepts and Theory in Comparative Fascist Studies
}

\author{
Tomislav Dulić \\ Hugo Valentin Centre, Uppsala University, Uppsala, Sweden \\ tomislav.dulic@valentin.uu.se
}

\begin{abstract}
Scholars have recently begun advocating for the application of social movement theory in the analysis of the rise and development of fascist political entities. While representing a welcome effort to increase the theoretical depth in the analysis of fascism, the approach remains hampered by conceptual deficiencies. The author addresses some of these by the help of a critical discussion that problematises the often incoherent ways in which the concept of 'movement' is used when describing fascist political activity both within and across national borders. The analysis then turns to the application of social movement theory to the historical example of the Ustašas. While recent research on social movements has begun to explore the role and character of transnationalism, this case study analysis suggests that the lack of supra-national organisations during the period of 'classic' fascism prevented the emergence of a 'transnational public space' where fascist movements could have participated. The conclusion is that rather than acting and organising on a 'transnational' level, fascist entities appear to have limited themselves to state-based international 'knowledge-transfer' of a traditional type.
\end{abstract}

\section{Keywords}

Croatia - fascism - social movements - transnationalism - Ustaša (U HRO)

In a recent article, Kevin Passmore argued for the need to use social movement theory in the analysis of fascism. Departing from a critique of 'generic 
fascism, he rebuked scholars for straying from the study of fascism per se to analysing fascist practice in terms of institutional structures, symbolic actions, or violence. He also argued that scholars have applied an outdated approach to the analysis of these fascist movements, relying 'unwittingly on understandings of social action derived from late nineteenth-century crowd psychology, from which social movement theory has-in principle-liberated itself.' ${ }^{1}$ According to Passmore, a more sophisticated application of social movement theory has the potential for a more dynamic approach that can better capture the nature and transformation of fascist movements on both national and transnational levels. ${ }^{2}$ At the same time and somewhat surprisingly, however, he dismissed efforts to 'enter into the (irresolvable) debate about whether or not they actually were fascist or indeed whether or not they were social movements.' ${ }^{3}$ Instead, he provided an analysis of the way fascists appropriated the concept 'movement' to seek legitimacy. While interesting, the approach also resulted in a lack of conceptual clarity that sometimes becomes confusing. In a reference to the Hungarian Arrow Cross, for instance, he argued ' $\mathrm{t}]$ he party was more genuinely a social movement than earlier far-right groups had been [my emphases]: ${ }^{4}$

Notwithstanding the conceptual deficiencies, Passmore's valuable impasse highlights issues that have not attracted enough attention in comparative fascist studies. Does it make sense to define fascist entities as social or political movements? If so, can social movement theory help improve the analysis of how fascist entities emerge, develop and transform? What can we learn from recent advances in theory about transnational social movements when discussing fascist cross-border cooperation? This article represents an effort to explore these issues by using the Ustašas as an empirical example for a discussion of the term 'movement' and its applicability to fascist entities, and also to explore fascist cross-border collaboration. The conclusion is that the Ustašas headed an organisation rather than a movement, which is likely to be also true

1 Kevin Passmore, 'Fascism as a Social Movement in a Transnational Context,' in The History of Social Movements in Global Perspective: A Survey, ed. Stefan Berger and Holger Nehring (London: Palgrave Macmillan UK, 2017), 572.

2 Ibid.

3 Ibid., 583 .

4 Ibid., 6o2. A similar problem can be found in Bauerkämper and Rossilinski-Liebe's interesting Fascism Without Borders, where the former continuously refers to 'movements and regimes'. Even though the authors do not provide a definition that can distinguish between movements and regimes, it seems all fascist organisations that are not regimes-in other words in control of a state apparatus - are defined as 'movements'; Arnd Bauerkämper and Grzegorz Rossoliński, ed., Fascism Without Borders: Transnational Connections and Cooperation Between Movements and Regimes in Europe from 1918 to 1945 (New York: Berghahn Books, 2017), 11. 
for many other fascist entities that are regularly referred to as movements in the literature. Based on an empirical analysis of Ustaša activities in Yugoslavia, Italy, Hungary and Germany, I furthermore suggest that scholars revisit the concept of transnationalism, due to its strong association with late twentieth-century globalisation processes and the emergence of a transnational public space that one cannot easily find in interwar Europe.

\section{The Concept of 'Movement' and its Use in Fascist Studies}

The conceptual puzzle was first brought to my attention almost two decades ago when I noted the inconsistent manner in which the Ustašas referred to themselves and their role in Croatian society. Their official name was UstašaCroatian Revolutionary Organisation [UHRO; Ustaša-Hrvatska revolucionarna organizacija]. However, already in some of the founding documents the Ustašas often referred to themselves as a movement (pokret), ${ }^{5}$ a term that became dominant in the Independent State of Croatia [NDH; Nezavisna Država Hrvatska]. The choice of terminology was not surprising, considering the character and activities of the UHRO. It is in the raison d'être of fascist leaders and groups to portray themselves as representing 'the People', in other words as an entity that transcends the body politic to embody a 'popular will'. Parties and other organisations, by contrast, speak on behalf of classes or other sub-groups within the national community, which means they are divisive and competitive in character. Self-defining as a party therefore implies that one is merely representing one of many political alternatives, competing in a 'market of ideas' for the support of a constituency. Having gained power through a campaign of anti-democratic activities and collaboration with the Axis Powers, the Ustašas could therefore not style themselves as a 'party', since that would contradict the very essence of fascism as an alternative to a supposedly dysfunctional democracy.

What I found intriguing was that many scholars referred to the UHRO as a movement with little or no discussion of the conceptual and theoretical implications for doing so, while at the same time conceding they had few followers and were largely inactive in Yugoslavia during most of the interwar period. ${ }^{6}$ One can

5 Nevenko Bartulin, The Racial Idea in the Independent State of Croatia: Origins and Theory, Vol. 4 (Leiden: Brill, 2014), 127.

6 Fikreta Jelić-Butić belonged to the few Yugoslav scholars that showed an awareness of the problem by pointing out that the Ustašas use of the concept movement 'should be understood only in the formal sense of the word'; Fikreta Jelić-Butić, Ustaše i NDH (Zagreb: SN Liber Školska knjiga, 1977), 8. 
find a similar lack of conceptual stringency in comparative fascist studies, where the term 'movement' is used for an array of organisations. ${ }^{7}$ Sometimes, such as with the Finnish Lapuan liike [Lapua Movement], one can perhaps speak of the kind of network that signifies a movement. ${ }^{8}$ Defining the Norwegian Nasjonal Samling as a movement is less convincing, considering it was established as a political party in 1933 even before it had become 'fascistised'. ${ }^{9}$ Similar problems exist insofar as more well-known fascists are concerned. While Mussolini's Fasci d'Azione Rivoluzionaria may be considered a movement in its early stages, this is hardly the case with the Partito Nazionale Fascista (PNF), which already in 1921 'aimed to redirect the movement's activities to more conventional political and parliamentary activity'.10 The situation is clearer with the Nationalsozialistischer Deutsche Arbeiterpartei (NSDAP), which already in 1921 had a hierarchical organisational structure and a 25-point party programme. ${ }^{11}$ Even after being banned in 1923, the organisation continued its work as part of the Völkisch-Sozial Blok until coming to power in 1933. The Spanish Falange Española de las jons emerged as a fascist party in 1934 under a collective leadership comprising Ramiro Ledesma,

7 This is a weak spot in Bauerkämper and Rossiliński-Liebe's edited volume, where the authors argue that '[i]n conceptual terms, at least three dimensions of 'transnational fascism' are to be distinguished', none of them being whether or not we are dealing with movements or not, after which they intermittently refer to 'fascist movements and regimes'; Bauerkämper and Rossoliński, Fascism Without Borders, 2, passim.

8 The movement emerged in 1929 as a reaction to communist activities and its ideology was characterised by extreme nationalism, anticommunism and its activities by frequent use of violence for political purposes. As a result of the violent activities and the so-called Mäntsäla Uprising in 1932 (when demands were put forward to also prohibit the Social-Democratic Party) the government declared the movement illegal and it subsequently transformed into Isänmaallinen kansanliike [The Fartherland Party]; Ylva Stubbergaard, Stat, kris och demokrati: Lapporörelsens inflytande i Finland 1929-1932 (Lund: Arkiv, 1996), 189-195.

9 In his seminal study on fascism, Uglevik Larsen also points out that it is problematic to use the term 'fascist' for Nasjonal Samling and many of its members, although 'it was similar to such parties on some crucial points of comparison, having e.g. adopted some of its party program and organisational structure from the NSDAP'; Stein Ugelvik Larsen, Bernt Hagtvet, and Jan Petter Myklebust, Who Were the Fascists: Social Roots of European Fascism (Bergen: Universitetsforlaget, 1980), 595 .

10 Philip Morgan, Italian Fascism, 1915-1945, 2nd ed. (Basingstoke: Palgrave Macmillan, 2003), 45 .

11 The inconsistency can be illustrated through The Wiley-Blackwell Encyclopedia of Social and Political Movements. In Reichardt's entry on 'fascist movements' we are told that they are characterised by ' $[t]$ he absence of stable organs of decision-making or a bureaucratic movement structure', while in Brustein's entry on the 'Nazi movement' we read that Hitler within a very short time after taking over he succeeded in establish 'complete authority' while also issuing a 25-point party programme; David A. Snow et al., The Wiley-Blackwell Encyclopedia of Social and Political Movements, Vol. I (Chichester: Wiley-Blackwell, 2013), $456,824-826$. 
Ruiz de Alda and José Antonio Primo de Rivera. Once the Falangists reorganised through a merger with Carlism under the direction of Francisco Franco, they transformed into a party and monopolised political power in the government. ${ }^{12}$ Scholars have referred to all of these entities as 'movements', sometimes by lumping them together under 'fascist organisations and movements. ${ }^{13}$

The 'transnational turn' in fascist studies has moreover led to a gradual expansion of the attention to 'European' or even 'global' fascism, ${ }^{14}$ with references being made to 'transnational fascism, ${ }^{15}$ or 'transnational fascist movements.' ${ }^{16}$ The trend raises a new set of questions, which concern the very concept of transnationalism and its relation to movements. Theorists agree that transnational social movements (TSM) are spreading and gaining in importance, with some arguing one should not only consider them a result of recent globalisation trends but that some have existed for considerable time. However, one also runs into a host of problems concerning the character of TSM, their relationship to national movements, state authorities and international organisations. What is at stake is to understand if transnational movements act outside the framework of national movements that have access to governments and polities; if their focus is on interaction with international organisations; or if they coordinate and provide legitimacy for national movements and organisations. ${ }^{17}$ While the number of publications dealing with

12 Stanley G. Payne, The Franco Regime, 1936-1975 (Madison, Wis: University of Wisconsin Press, 1987), 52-59.

13 Bauerkämper and Rossoliński-Liebe's otherwise important contribution is a case in point. While referring to 'cooperation between movements and regimes' in the title, the introduction only contains a discussion about 'transnational fascism' and no effort to discuss how ideology and political praxis might be affected by the character of the entity, or whether one can actually speak about transnational movements in the 193os; Bauerkämper and Rossoliński, Fascism Without Borders, 1-18.

14 See Stefan Berger and Holger Nehring, The History of Social Movements in Global Perspective: A Survey (London: Palgrave Macmillan, 2017); Raimo Vayrynen, 'Sovereignty, Globalization and Transnational Social Movements,' International Relations of the AsiaPacific 1, no. 2 (2001): 227-246; Dawn Wiest and Jackie Smith, 'Explaining Participation in Regional Transnational Social Movement Organizations,' International Journal of Comparative Sociology 48, no. 2-3 (2007): 137-166.

15 Ángel Alcalde, 'Towards Transnational Fascism: German Perceptions of Mussolini's Fascists and the Early NSDAP,' Politics, Religion \& Ideology 19, no. 2 (2018): 176-195.

16 Samuel Huston Goodfellow, 'Fascism as a Transnational Movement: The Case of Inter-War Alsace,' Contemporary European History 22, no. 1 (2013): 87-106.

17 John A. Guidry, Michael D. Kennedy, and Mayer N. Zald, Globalizations and Social Movements: Culture, Power, and the Transnational Public Sphere (Ann Arbor: University of Michigan Press, 2000), 7-8. 
transnational fascism has increased dramatically over recent years, few except Passmore have even addressed these issues conceptually.

\section{Theorising Social Movements}

It is easy to understand why someone would refrain from venturing into the cumbersome task of defining social movements, considering the plethora of sometimes contradictory definitions. To begin with popularised perceptions of the concept, Wikipedia relies on Shannon Deric's definition of social movements 'as organisational structures and strategies that may empower oppressed populations to mount effective challenges and resist the more powerful and advantaged elites. ${ }^{18}$ Encyclopaedia Britannica, by contrast, defines social movements as a loosely organised but sustained campaign in support of a social goal, typically either the implementation or the prevention of a change in society's structure or values. ${ }^{19}$ Even though similarities exist between the definitions, the latter do not necessarily view movements as a reaction of the oppressed, while also allowing the inclusion of conservative movements that strive for the prevention of change. The definitions also diverge regarding the organisational form that characterises movements. While the former refers to 'organisational structures', the latter focuses on the movement as action rather than entity by putting the focus on the campaign rather than on the agent. We find similar distinctions in Tilly's definition of the social movement as 'a sustained series of interaction between power-holders and persons successfully claiming to speak on behalf of a constituency lacking formal representation, in the course of which these persons make publicly visible claims for changes in the distribution of the exercise of power, and back those demands with public demonstrations of support.'. 20

John McCarthy and Meyer N. Zald take the discussion in a slightly different direction by defining movements as 'a set of opinions and beliefs in a population, which represents preferences for changing some elements of the social structure and/or reward distribution of a society'. ${ }^{21}$ Rucht has criticised both,

18 'Social Movement,' Wikipedia, https://en.wikipedia.org/wiki/Social_movement\#cite_note:0-4, accessed February 15, 2021. See also Davita Silfen Glasberg and Deric Shannon, Political Sociology: Oppression, Resistance, and the State (Thousand Oaks, Calif. and London: Pine Forge Press/Sage Publications, 2011), 15 o.

19 'Social movement,' Britannica.com, accessed February 15, 2021, https://www.britannica.com/ topic/social-movement.

20 Charles Tilly, From Mobilization to Revolution (New York: McGraw-Hill, 1978), 304.

21 J. Craig Jenkins, 'Resource Mobilization Theory and the Study of Social Movements,' Annual Review of Sociology 9, no. 1 (1983): 1217-1218. 
positing that if defined as a series of interactions then the social movement would confound those seeking change with the government they conflict with. Meyer and Zald instead risk including those who may sympathise with a movement while doing nothing to support its activities. Rucht emphasises action to a higher degree, describing the social movement as '[a] network of individuals, groups and organisations that, based on a sense of collective identity, seek to bring about social change (or resist social change) primarily by way of collective public protest. ${ }^{22}$

Rucht's definition provides a useful starting point for an analysis of fascist movements. While presupposing the existence of some form of structure, the definition does not restrict itself to movements driven by a reaction of the oppressed and those seeking change. He also points out that while not being an organisation, a movement can within its network include organisations, 'even those with a highly formalized character such as a political party.' ${ }^{23}$ Interestingly, here one finds a contradiction between Passmore's reference to Rucht and the claim that 'one cannot solve the problem by dividing fascist organizations into social and political components either, or indeed by distinguishing between fascism-movement and fascism-regime. ${ }^{24}$ As it turns out, Rucht bases such distinctions on power relations: 'Given this heterogeneity of movement structures, it is no wonder that we may find within movements also those organizational forms which we have analytically separated from movements, that is, interest groups and political parties. Only when one of these organizations succeeds in reaching a hegemonic position-controlling virtually all collective resources-would I no longer consider it a movement.'25

Rucht's observation brings us to a conclusion of key importance. From the fact that fascist organisations and regimes like those in Italy or Hungary controlled 'all collective resources' in their respective countries, it follows that fascist networks would cease to make up movements after monopolising power, and certainly after becoming the regime of a state. What is at stake, therefore,

22 Dieter Rucht, 'Studying Social Movements: Some Conceptual Challenges,' in The History of Social Movements in Global Perspective: A Survey, ed. Stefan Berger and Holger Nehring (London: Palgrave Macmillan UK, 2017).

23 Ibid., 44.

24 Passmore, 'Fascism as Social Movement,' 582.

25 Dieter Rucht, 'National Context and Movement Structures,' in Comparative Perspectives on Social Movements: Political Opportunities, Mobilizing Structures, and Cultural Framings, ed. Doug MacAdam, John D. McCarthy and Mayer N. Zald (New York: Cambridge University Press, 1996), 188. Diani concurs, positing that in '[w] hen this happens, as in the instances of the Bolshevik Party in Russia or the National Socialist Party in Germany, it is more important to drop the term "movement" altogether and concentrate instead on the concept of political organization'; Mario Diani and Doug McAdam, Social Movements and Networks: Relational Approaches to Collective Action (Oxford: Oxford University Press, 2003), 9-10. 
is to understand the differences between movements and organisations and the effects these might have on the strategies that will be applied depending on structure. As will be shown below, it would also seem that fascists, while using the term 'movement' as a way of rhetorically implying a popular support that transcends class and other socio-economic delineations within a national community, were fundamentally opposed to the very principles that provide the basis for how social movements are organised.

\section{Distinguishing Between Organisations and Movements}

If movements 'have no top and clear center' while being something else than organisations, ${ }^{26}$ what then distinguishes one from the other? Four of the key features characterising organisations are that they a) do not seek to achieve revolutionary societal change, $b$ ) try to maintain long-term stability by c) systematising the work process and d) formalising decision-making procedures. ${ }^{27}$ Therefore, while movements have no formalised decision-making procedures and usually dissolve or transform once they achieve their goals (they are 'goal-oriented'), organisations such as parties and interest groups focus on servicing a constituency or clients by performing activities in demand (they are 'activity-oriented'). Another aspect is that movements orient their activities towards entire social groups or classes, including those that take no active part in the movement (e.g. working-class movement). Organisations are instead client or member-oriented (e.g. Alcoholics Anonymous), although they may also have a wider societal impact (for instance through the work of political parties).

Specialists have also identified a category of entities that bridge the dichotomy between movement and political organisations, referred to in the literature somewhat ambiguously as 'party movements' (or 'movement parties'). ${ }^{28}$ These entities are often defined as 'organizations [my emphasis] that have attributes of both political parties and social movements.' ${ }^{29}$ Specifically, they seek to overcome the shortcomings movements often grapple with in terms of maintaining organisational stability and having access to legislative bodies.

26 Rucht, 'Studying Social Movements,' 44.

27 'Formal organization,' Encyclopaedia Britannica Academic, accessd June 23, 2019, https:// www.britannica.com/topic/formal-organization.

28 See Marina Prentoulis and Lasse Thomassen, Movement Parties (Abingdon, Oxon; New York, NY: Routledge, 2020).

29 Mildred A. Schwartz, 'Party Movements,' in Oxford Research Encyclopedias, Politics (Oxford: Oxford University Press, 2020). 
At the same time, they make use of movement strategies for the purpose of a mobilisation that provides grassroots-level legitimacy. ${ }^{30}$ As pointed out by Minkenberg, it should therefore come as no surprise that movement parties have become a hallmark of the populist Right:

Unlike other movement parties (such as the Greens in their early stages), radical right parties usually do not emanate from social movements, yet 'apply the organizational and strategic practices of social movements in the arena of party competition'. Moreover, based on their activists' and supporters' basic value orientations and the radical right's particular (anti-egalitarian, top-down) approach to politics, radical right parties typically exhibit the characteristics of a charismatic leadership which runs the party in an authoritarian fashion and lends the party organizational stability. ${ }^{31}$

The observation alludes to the fact that organisation charts, formalised decision-making bodies and procedures are distinguishing features of formal organisations, which exist in parallel with informal organisations. This does not mean the latter lack hierarchies; these exist with the difference that decision-making takes place through informal channels, with leaders gaining legitimacy through interpersonal relationships, loyalties and personal charisma. The distinction draws on Max Weber's division of the three different grounds for legitimising the right to authority:

Rational grounds - resting on a belief in the 'legality' of patterns of normative rules and the right of those elevated to authority under such rules to issue commands (legal authority). Traditional grounds - resting on an established belief in the sanctity of immemorial traditions and the legitimacy of the status of those exercising authority under them (traditional authority); or finally, charismatic grounds - resting on the devotion to the specific and exceptional sanctity, heroism or exemplary character of a person, and of the normative patterns or order revealed or ordained by him (charismatic authority). ${ }^{32}$

30 Ibid.

31 Michael Minkenberg, 'Between Party and Movement: Conceptual and Empirical Considerations of the Radical Right's Organizational Boundaries and Mobilization Processes,' European Societies 21, no. 4 (2019): 466. The author used the Austrian Freedom Party, Lega Nord and the Swiss People's Party as examples of party movements; Ibid. 467.

32 Max Weber, A. M. Henderson and Talcott Parsons, The Theory of Social and Economic Organization (New York: Oxford University Press, 2012), 328; see also Kieran Allen, Max Weber: A Critical Introduction (London: Pluto Press, 2004), 100. 
Weber's classification provides a means by which to separate different decision-making bodies and processes, with movements having certain similarities with informal organisations. Specifically, leaders of social movements cannot claim legal authority and instead rely on a charismatic leadership that provides popular legitimacy and strengthens their influence in contact with other actors within and outside the governmental structures. ${ }^{33}$ Parties, on the other hand, are usually governed by legal-rational decision-making procedures and seek direct access to legislative bodies. Although being organisations - and often highly centralised, top-down ones at that-movement parties instead apply movement strategies to overcome limitations insofar as representation is concerned, while sometimes being part of movements.

To summarise, social movements differ from organisations but may include what is often referred to as social movement organisations (sMOs) within the network of entities that make up the movement. ${ }^{34}$ The smo s help articulate policies, influence policy-makers and guide movement activities towards the achievement of goals common to the movement. Such processes do not happen in a vacuum and the interaction between sMos and authorities sometimes also leads to the transformation of the former along what Kriesi has identified as four basic 'trajectories'. ${ }^{55}$ One development is to move toward institutionalisation. This means the organisation keeps its orientation towards influencing authorities, but relinquishes direct participation as a critical feature for the benefit of a formalisation of the decision-making process (the typical example is when a smo turns into a political party). The second trajectory leads towards commercialisation, transforming the SMO into a service-provider to external 'clients', which also entails a drastic reduction of direct participation in activities. The third trajectory results in an involution whereby the SMo transforms into a service-provider that allows direct participation in activities, although moving from being oriented towards authorities to focus on the SMO constituency. This typically happens when the smo abandons the desire to achieve social or political change and retreats into becoming an advocacy group representing particular socio-economic or cultural substrata in society. One aspect Kriesi did not develop that much concerns the radicalisation of the smo. Here, he builds on Zald and Ash, who attribute radicalisation to a combination of a charismatic leader and the emergence of an oligarchy that is more radical than

33 Snow et al., The Wiley-Blackwell Encyclopedia of Social and Political Movements, I, 176.

34 Ibid., 1196.

35 Hanspeter Kriesi, 'New Social Movements in a Political Context,' in Comparative Perspectives on Social Movements: Political Opportunities, Mobilizing Structures, and Cultural Framings, ed. Doug MacAdam, John D. McCarthy and N. Zald Mayer (New York: Cambridge University Press, 1996). 


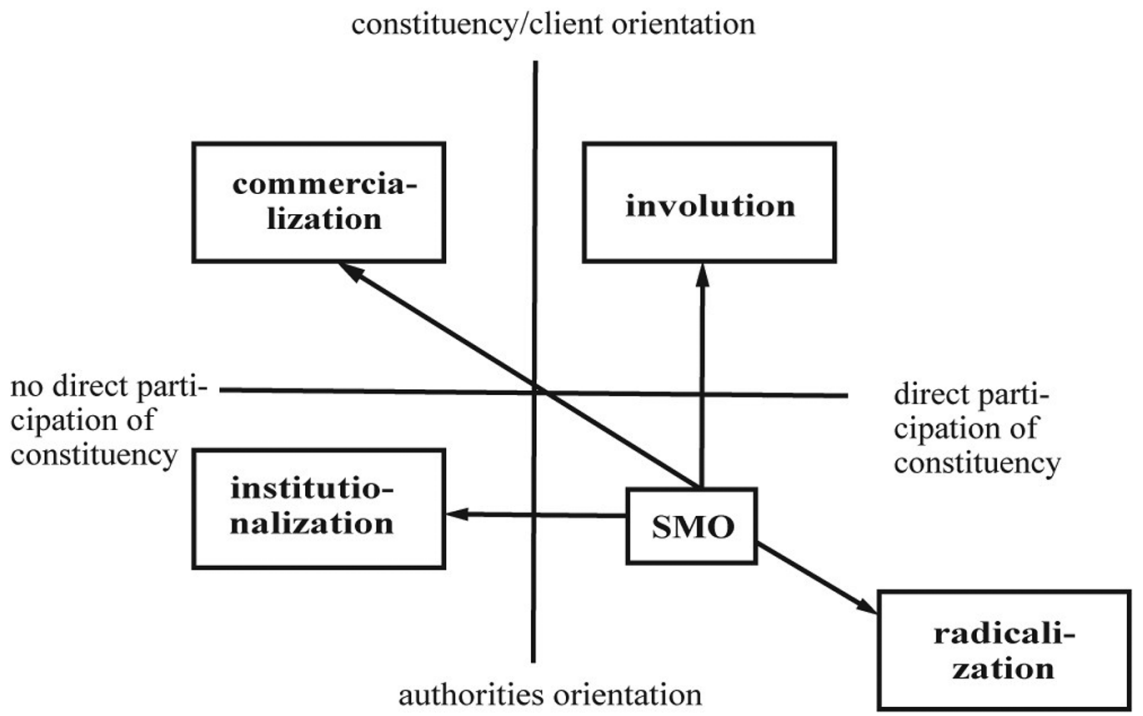

FIGURE 1 Kriesi's Trajectory of Social Movement Organisations. Source: Kriesi, Hanspeter, 'New Social Movements in a Political Context,' in Comparative Perspectives on Social Movements: Political Opportunities, Mobilizing Structures, and Cultural Framings, ed. Doug MacAdam, John D. McCarthy and Mayer N. Zald (New York: Cambridge University Press, 1996), 157. Reproduced with permission.

an increasingly apathetic core constituency. Leadership thus becomes critical, as it is the role of the charismatic leader to mobilise the constituencies for action. ${ }^{36}$

\section{Contentious Politics}

While some of the early thinkers believed the social movement emerged due to the type of 'crowd psychology' Passmore argues has influenced fascist

36 Mayer N. Zald and Roberta Ash, 'Social Movement Organizations: Growth, Decay and Change,' Social Forces 44, no. 3 (1966): 338-339. More recent research has rediscovered Mathiesen's concept of 'the unfinished' to explain how 'abolitionist' movements radicalise to achieve sweeping political and social change; Andreas Armborst, 'Radicalisation and De-radicalisation of Social Movements: The Comeback of Political Islam?' Crime, Law and Social Change 62, no. 3 (2014). For an implementation of the model on the UHRO, see Tomislav Dulić and Goran Miljan, 'The Ustašas and Fascism: "Abolitionism”, Revolution, and Ideology (1929-1942), Journal of Soviet and Post-Soviet Politics and Society 6, no. 1 (2020): 281-309. 
studies, ${ }^{37}$ adherents of Mass Society Theory instead focused on how individuals joined extreme movements because of a sense of isolation brought about by the increasing individualism of modern society. ${ }^{38}$ As argued by Tarrow, however, Marxism probably provided the most persuasive framework through its emphasis on 'relative deprivation', although constantly grappling with the issue of mass mobilisation. Departing from a structuralist approach, Marx did not bother too much about exploring how the mobilisation would happen. Rather, he viewed the emergence and growth of social movements as a natural consequence of the inherent contradictions in the capitalist mode of production, which resulted in an alienation and grievances that would enable mobilisation. Disenchanted with the passivity of the working class, however, Lenin looked for the answer in a 'top-down' approach that resulted in his idea about a vanguard spearheading collective action. Gramsci, finally, believed the answer to the limited capability of the working class to mobilise 'from below' was a matter of a class-consciousness that he believed could be developed by the help of 'cultural hegemony' ${ }^{39}$

The post-Second World War period saw the development of several theoretical approaches, most of which were essentially critical of the 'relative deprivation model' that had dominated the previous period. McCarthy, Zald and other adherents of the 'resource mobilisation theory' came to exert a profound influence on the field with a rational-choice inspired focus on how movements identify goals, formulate strategies and mobilise human, infrastructural, financial, ideational and other resources in pursuit of movement goals. ${ }^{40}$ Another strand of thought had its roots in the Gramscian perspective and focused on so-called framing processes, in other words how the movement would appeal to the general public and thus achieve mobilisation through the proliferation of 'collective action frames'. ${ }^{41}$ Being an adherent of what later became known as political opportunity theory, Tilly sought to understand why certain movements succeed while others did not by shifting focus to the public space in which movements engage with policy-makers and other individual and collective actors. He divided the space into a relatively secluded 'polity', in which parties and other influential actors have direct access to political decision-making

37 Gustave Le Bon, The Crowd: A Study of the Popular Mind (London: T. Fisher Unwin, 1897).

38 See William Kornhauser, The Politics of Mass Society (London: Routledge \& Kegan Paul, 1960).

39 Sidney G. Tarrow, Power in Movement: Social Movements and Contentious Politics, 3 rd rev. and updat. ed. (Cambridge; New York: Cambridge University Press, 2011), 17-20.

40 Jenkins, 'Resource Mobilization Theory and the Study of Social Movements,' $532-533$.

41 Robert D. Benford and David A. Snow, 'Framing Processes and Social Movements: An Overview and Assessment,' Annual review of sociology 26, no. 1 (2000): 611-639. 


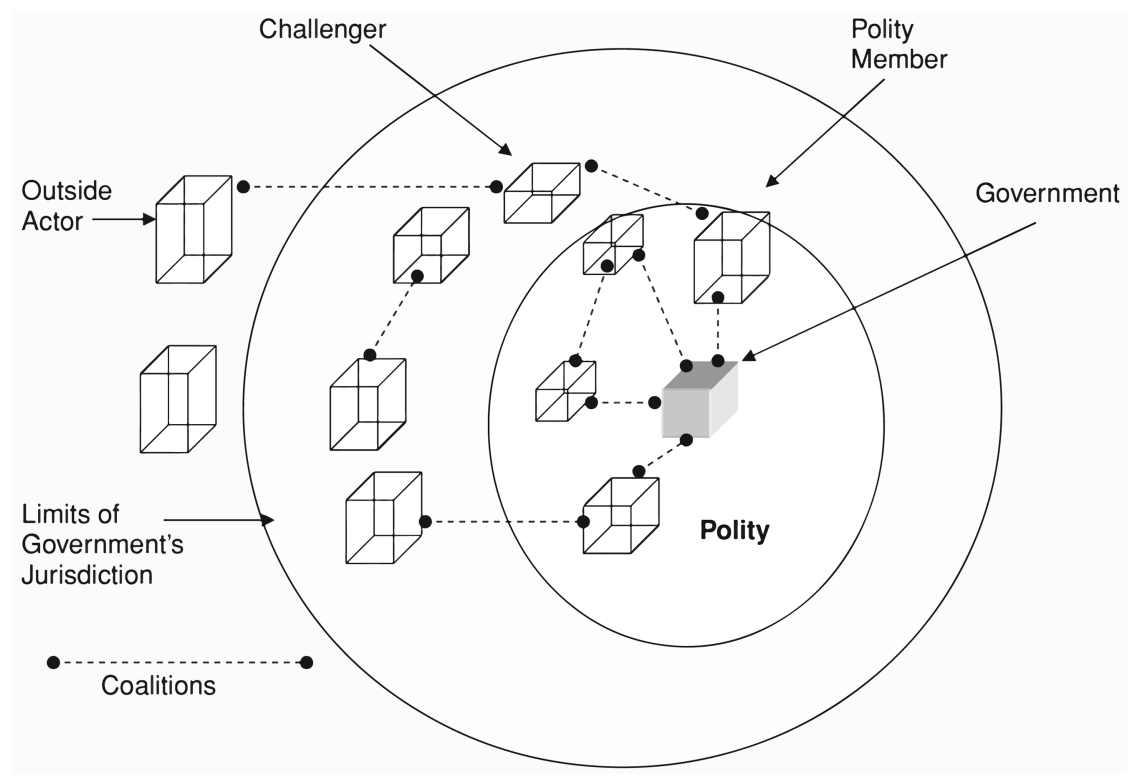

FIGURE 2 Tilly's Polity Model. Source: Sidney G. Tarrow, Power in Movement:Social Movements and Contentious Politics (Cambridge and New York: Cambridge University Press, 2011), 21. Reproduced with permission.

bodies, and an area outside the polity where there is no such direct access. Being deprived of such access, challengers engage in coalition-building with members of the polity or other 'outsiders' who have access to such actors, while balancing between opportunities and threats. The authorities, for their part, either facilitate movement activity by lowering the cost for mobilisation, or resort to repression. ${ }^{42}$

The character of the movement, its aims and the political context in which it engages with the authority will furthermore affect the strategies it uses to achieve its aims and goals, as well as the reactions of the authority. While some movements will focus on the mobilisation of human, material and cultural resources to influence the polity, others will turn to 'agenda-setting' via media to create awareness-making, maintain in-group cohesion and attract followers. Tilly's approach involves what Tarrow termed 'contentious politics', which includes various forms of disruption such as sit-ins, public disturbances, rioting and intimidation, which are applied to increase pressure on the authorities. Following Minkenberg, it seems this strategy is the most interesting to apply when analysing right-wing "movement parties":

42 Tilly, From Mobilization to Revolution, 100, 33. 
This organizational stability of successful radical right parties notwithstanding, they clearly qualify as movement parties in that they are continuously engaged in 'contentious politics' as defined by Tilly and Tarrow, that is, a process of collective claims making at the interplay of contention, collective action and politics. They do not only challenge governments as 'targets, initiators of claims, or third parties'. They challenge all other parties or even the political order in a populist style, rather than merely seeking office or a change in policy. ${ }^{43}$

Even though Tilly provides a useful framework for the analysis of processes of contention and the situations in which movements emerge, he also confined it to the interplay between national governments and movements seeking to influence or even overthrow them. While allowing for the existence of 'outside actors', the model does not elaborate much on their interaction with external state-based polities. This means Tilly's model is restricted to a national perspective that does not account for the activities of transnational social movements.

\section{Movement Activities in a 'Transnational Space'}

Turning to transnationalism as a phenomenon, it appears that fascist entities by and large restricted activities across national borders to various forms of knowledge-transfer, rather than to coordinate contentious action directed against international bodies or national governments. To define such forms of cross-border interaction as transnationalism represents a departure from what social scientists understand as transnationalism or transnational social movements. Khagram et al., for instance, refer to three forms of transnational activities, including transnational advocacy networks (focusing on information-exchange between non-governmental bodies in at least three countries), transnational coalitions (coordinating shared strategies to bring about social change) and transnational social movements (who mobilise sustained activities in more than one country for the purpose of achieving social change). ${ }^{44}$ According to the authors, these 'share some collective beliefs or collective action frames' and seek to influence norms in an 'international arena., ${ }^{45}$ Drawing on

43 Minkenberg, 'Between Party and Movement,' 467.

44 Sanjeev Khagram, James V. Riker and Kathryn Sikkink, 'From Santiago to Seattle: Transnational Advocacy Groups Restructuring World Politics', in Restructuring World Politics: Transnational Social Movements, Networks, and Norms, ed. Sanjeev Khagram, James V. Riker and Kathryn Sikkink (University of Minnesota Press, 2002).

Ibid., 15 . 
Habermas, Guidry et al. define the arena as a space beyond national boundaries that movements and organisations enter in pursuit of goals that cannot be adequately addressed on a national level:

Globalisation has in fact brought social movements together across borders in a 'transnational public sphere', a real as well as conceptual space in which movement organizations interact, contest each other and their objects, and learn from each other. 'Action at a distance' does not really occur from a distance. This action originates somewhere, proceeds through specific channels, does something, and has concrete effects in particular places. That action is, however, mediated by discursive relationships that are forged in a transnational public sphere. ${ }^{46}$

One way of explaining the difference between transnationalism and international cooperation, in other words, is to depart from the Latin etymology and view trans-nationalism as political activism 'above' or 'beyond' the national level. Inter-national cooperation, by contrast, happens 'between' or 'among' state-based entities that may engage in information exchange but do not act in a transnational public space. However, the advancements have also unearthed many controversies concerning political opportunity and mobilisation structures and their relationship to the transnational space. As pointed out by Hanna, TSM s often struggle when seeking to achieve a common 'global good' due to the fact that international bodies lack the coercive means that remain tightly associated with state sovereignty: 'Despite globalization, there is nothing to suggest state sovereignty is losing much of its operational value in legal and political decision making, and thus one can hardly expect programmatic and sustained attempts to address climate change or nuclear weapons, for example, without some kind of engagement with international institutions and, at least, the prospect of inducing the action of nation-states. ${ }^{47}$

What relevance does this have for studies of 'transnational fascism' and how are we to understand cross-border cooperation during the interwar period? If considering that transnationalism plays out in a 'transnational public space' above and beyond the nation-state, one immediately runs into two problems of relevance. Firstly, one needs to identify a transnational public space that

46 John Guidry, Michael D. Kennedy, and Mayer Zald, 'Globalizations and Social Movements,' in Globalizations and Social Movements: Culture, Power, and the Transnational Public Sphere (Ann Arbor: University of Michigan Press, 200o), 3.

47 Mark Hanna, 'Between Law and Transnational Social Movement Organizations: Stabilizing Expectations of Global Public Goods,' Journal of Law and Society 44, no. 3 (2017): 347. 

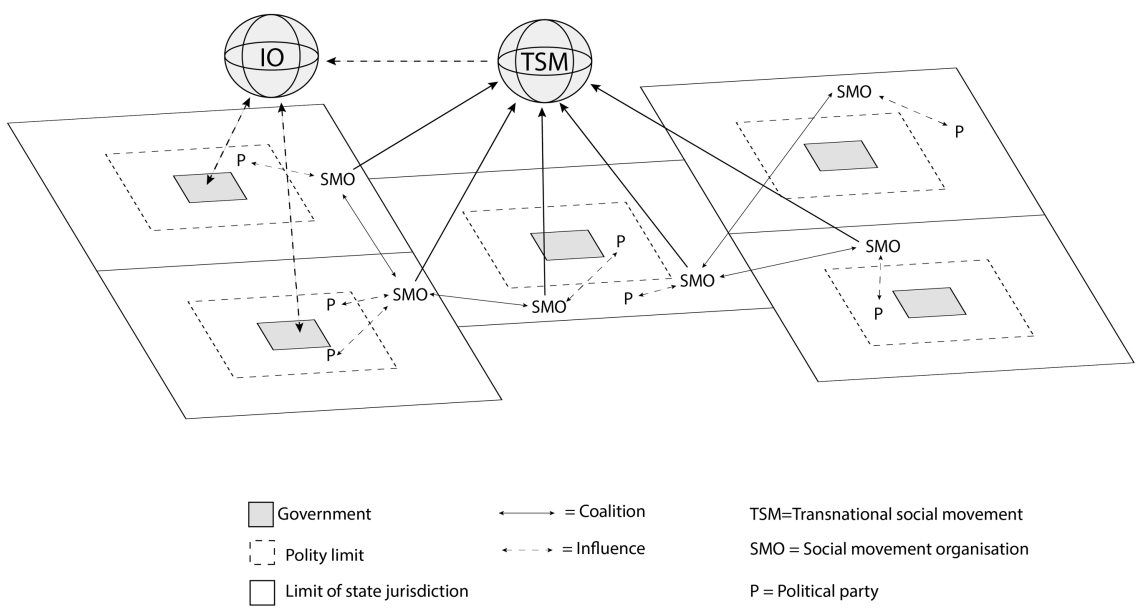

FIGURE 3 Matrix of Transnational Social Movement Activity.

provides fascist entities - whether movements or SMOs-with an arena in which to act. This appears to be a challenge at a time when the development of an international political arena with inter-governmental bodies hardly existed with the exception of a few such as the League of Nations. Secondly, fascist political actors were by and large ardent opponents to 'internationalism' and any infringements on state sovereignty. Departing from how transnationalism has been understood in the theoretical fields from which the concept emerged, it therefore remains to be seen whether a transnational fascist movement that worked for a fascist 'global common good' by acting in a transnational public space ever existed.

To summarise, there is a need for the field of fascist studies to engage in a discussion with the concept of transnationalism in a logically coherent way that makes it possible to distinguish what is commonly understood as transnationalism from the type of exchange of goods, services and ideas that traditionally characterised international cooperation and which by and large happened on a bilateral level. To do so, I develop Tilly's model by proposing a matrix that provides an overview of how networks of international movements transcend jurisdictions and may influence governments in several countries by acting on a vertical 'transnational public space' identified by Guidry et al. to pursue a 'common good'. This allows accounting for the fact that when an actor finds itself outside the jurisdiction of one state it is almost always within the jurisdiction of another. I therefore divide the model into a grey box representing a government, a box with a dotted line representing the limit of a polity within each state and a full line representing the limits of state jurisdiction. Inside the jurisdiction, we have smos, which form coalitions (full arrow line) and seek to 
exert influence (dotted arrow line) on political parties or individuals ('P') and other organisations to influence the government and its policies. Adding to this is a vertical space containing a transnational social movement (TSM), which the state-based smos form part of. The model illustrates that TSMs differ from traditional state-based movements by not having a direct legal or other influence on polities. They can influence a variety of international bodies, even to the point of enacting laws and regulations on the international level, but since executive powers rest with sovereignty, the TSM will always be at a disadvantage if states refuse to pass regulations. The TSM is instead a network of state-based sMOs, through which it might affect national polities, although it may also influence governments through international organisations (IO) such as the UN. As a result, they instead seek to influence the nation-based smos, which for their part use references to international or transnational movements for the purpose of legitimizing their demands on authorities. Whether the organisations are part of transnational movements will furthermore affect political opportunity structures (the adoption of international treaties or laws might provide a window of opportunity for action), mobilisation structures (through the internationalisation of the recruitment base to include non-national members in national sMOs) and framing processes (by providing an argument for referring to international norms or threats as a means by which to mobilise constituencies). This also means SMO $\mathrm{A}$ in country $\mathrm{X}$ that is in no direct coalition with SMO B in country $Y$ can still exert an influence on the sMo through either SMO $\mathrm{C}$ in country $\mathrm{Z}$ or through the TSM $\mathrm{X}^{2}$. I furthermore assume the interactions between SMOs and TSMs will affect the ideational and structural evolution of the SMO, not least in terms of ideology, activism and framing.

\section{Empirical Analysis}

While there is debate regarding the exact date for the establishment of uHRO, scholars trace its origins to the interwar Hrvatska Stranka Prava [HSP; Croatian Party of Rights]. Ante Pavelić became the party secretary of HSP in 1927 when following a trip to Paris he travelled to Rome to hand over a memorandum regarding collaboration with the Italian regime to establish an independent Croatia under Italian tutelage. ${ }^{48}$ The next stage in his development came

48 I documenti diplomatici italiani, vol. V, Settima serie (Roma: Commissione per la pubblicazione dei documenti diplomatici, 1967), 303-305; see also Jozo Tomasevich, War and Revolution in Yugoslavia 1941-1945: Occupation and Collaboration (Stanford: Stanford University Press, 2001), зо. 
following the mortal wounding of Stjepan Radić, the leader of the Hrvatska seljačka stranka [Hss; Croatian Peasant's Party] in the Yugoslav parliament on 28 June $1928 .{ }^{49}$ Fearing a dissolution of the state, King Alexander abolished the constitution on 6 January 1941, which prompted Pavelić to leave for Bulgaria later the same month. In Sofia, he met Gustav Perčec and issued the 'Sofia Declaration', which stipulated cooperation with the Vnatrešna makedonska revolucionerna organisacija [VMRo; Internal Macedonian Revolutionary Organisation] for the dissolution of Yugoslavia. ${ }^{50}$ This stage in the evolution of UHRO is of theoretical importance, as it means that even before the existence of an Ustaša 'fascist movement' on Yugoslav soil, its leaders left the country altogether to seek support abroad. In Bulgaria, Pavelić met with members of a radical organisation with ties to members of the Bulgarian polity (albeit indirectly with the government), which were no more fascist at the time than the UHRO. In the early 1930s, these organisations can best be described as rightwing terrorist organisations working for national independence through political violence.

Pavelićs stay in Bulgaria had a profound effect on his further development as a politician and on the articulation of a radical agenda of the UHRO. First, by establishing contacts with VMro, he embarked on a strategy characterised by terrorist violence, resulting in the assassination of King Alexander II and French Foreign Minister Louis Barthou in Marseille in 1934. Second, his contacts with VMRO and the inflammatory speeches he gave provoked the Yugoslav government to sentence Pavelić to death in absentia on 17 July 1930. ${ }^{51}$ Third, it meant Pavelić became a pariah with no way back into the polity of Yugoslavia. He settled in Italy until 1931, where he found himself under internment because of the regicide in 1934. It was during this period that his political ideology underwent a further radicalisation.

\section{Establishment of UHRO}

The gradual process of fascistisation began after the formulation of the Constitution of the Ustaša Organisation in 1932, which also can be seen as the final stage in the establishment of a terrorist organisation. The Constitution defined UHRO as 'a revolutionary organisation', with the goal to establish an

49 Ibid., 25.

50 Jelić-Butić, Ustaše i NDH, 20.

51 Mario Jareb, Ustaško-domobranski pokret: od nastanka do travnja 1941. godine (Zagreb: Školska knj., 2006), 83. 
independent state 'throughout the entire national and historical territory' where Croats lived. ${ }^{52}$ It also stipulated that Croats would be the owners of all the 'real and spiritual assets' of the state after its creation. The Constitution then moves to a discussion of the organisational structure of UHRO, which the Ustaša based on a combination of Weber's legal-rational and charismatic principles of authority. First (points $3-6$ ), the principles described the organisational structure of the UHRO, subdivided into tabor, logor, stožer and Glavni Ustaški Stan [GUS; Ustaša Headquarters], which elected the Poglavnik, subordinated leaders (stožernik, logornik, tabornik) and various officials and specialists. The Constitution stipulated that 'any Croat' capable of carrying out the struggle and showing absolute loyalty could join the organisation, while only the Poglavnik had the right to relieve a member of his or her duties. It moreover contained the text of an oath of allegiance each new member had to swear and which envisaged complete obedience to the Poglavnik personally and other superiors under penalty of death. Two points $(12-13)$ regulated the work of the Ustaša Court and clarified that the Ustaša Headquarters would decide on some other matters relating to the organisational work.

Adding to the Constitution were fifteen (later expanded to seventeen) Ustaša Principles from June 1933, which had the aim of a) defining the Croatian nation as distinct from the 'eastern' Serbs and $b$ ) to give a historical motive for the establishment of an independent state. Points $1-5$ dealt with the ancient and medieval history of the Croats, describing them as a formed and organised nation at the time of arrival in their own Croatian state', the right to which it retained until the First World War. Points 8-12 dealt with the regenerative element of the Croatian nation and its right to rule, where one reiterated the historical right of Croats to recreate their own state throughout the historical and national territory. The Principles further stipulated that Croats 'belong to the western culture and civilisation'; that the peasantry formed the basis of the Croatian nation; and that only Croats 'by blood' had a place in the national community. ${ }^{53}$

Insofar as the organisational structure is concerned, it basically followed the leader principle to the letter, which is evident not least from the establishment of the GUS in 1932. The body represented a form of 'government-in-exile' that consisted of two parts: the Poglavnik's Adjutant Assembly (Poglavnički zbor) with seven members and a Council (Doglavničko vijeće) consisting of twelve

52 The ideological basis for these claims derived from 'pravaštvo' (from 'rights' in the legal sense), the idea that Croatia should be established on the entire territory of the state that joined in a personal union with the Hungarian King Coloman I in 1102.

53 The text of the Principles is reproduced in Jareb, Ustaško-domobranski pokret, 124-128. 
officials. As Jelić-Butić points out, the GUS was never formally convened and it is unclear who its members - which were formally appointed by Pavelićactually were. Accordingly, 'authority over the organisation was in the hands of the Ustasha leader, on whose will depended the position of each individual member, including the most prominent one', which lead her to conclude:

As the ideological and organisational founder of Ustashism, Pavelić tried his best to be the only inspirer in attracting and gathering members of the Ustasha organisation. In any case, this also influenced the formulation of the mentioned hierarchical status of the Ustasha organisation. Pavelic paid full attention to the creation of the Ustasha organisation not only in Italy, where he participated most directly, but in all other regions as well, where his most loyal associates created the Ustasha organisation exclusively on his behalf. Undoubtedly, due to personal interests, there was rivalry in the ranks of the Ustasha emigration, in other words conflicts between individuals and affluent or less influential Ustasha officials. However, there was no serious opposition to Pavelic himself even among the more influential groups, which could jeopardise his position and weaken his authority. 54

Jelić-Butićs characterisation of the UHRO illustrates that it was deeply engrained in the movement from the onset and allegiance to the Poglavnik was not merely a matter of paying lip service to the leader. Those who joined the UHRO did so in full knowledge of the fact that transgressions would result in their death (which also happened on a few occasions). The top echelons of the UнRо refrained from challenging Pavelić, with the notable exception of what seems to have been a half-hearted effort by Branko Jelić in the spring of 1934 to gain influence and possibly challenge Pavelić himself. The episode was nipped in the bud and if anything strengthened Pavelić as the undisputed leader of the UHRO for the duration of the interwar period. ${ }^{55}$ Looking back on the creation of the NDH state, Mile Budak (at the time Minister of Culture) argued in August 1941 that it 'was the deed of the Poglavnik ... others have participated as well, but without him - everything would ... wait for its leader.'56

54 Jelić-Butić, Ustaše $i$ NDH.

55 Mile Budak, 'Omladina je izvršila svoju dužnost,' in Ustaška mladež - omladinski prilog Ustaše, 3 August 1941, no. 5, 3, quoted in Goran Miljan, Croatia and the Rise of Fascism: The Youth Movement and the Ustasha During WWII (London, New York: I.B. Tauris, 2018), 53.

56 Goran Miljan, Croatia and The Rise of Fascism: The youth Movement and the Ustasha During WWII (London: I.B. Tauris, 2018), 53 . 
It is thus not only that there was no serious challenge to Pavelić; he became the centrepiece of a personal cult that turned him into the embodiment of the nation and the one individual without whom there would simply not be an independent Croatian state. This also meant the classic distinction between the legislative and executive branches of government did not exist in the $\mathrm{NDH}$, 'because all state powers were transferred into the hands of the executive [branch] headed by the Poglavnik. ${ }^{57}$

\section{Transnational Activities}

The extent to which the UHRO became fully 'fascistised' in the 1930s has been debated and is a topic that cannot be dealt with in detail here. ${ }^{58}$ Suffice it to say that while the Ustaša did not elaborate very much on fascist ideology and its relationship to the Croatian nation in the first half of the 193os, Pavelic firmly positioned Ustaštvo in the camp of European fascism. This is clear in his book Strahote zabluda (published in Siena in 1938). The book represented a thorough dismissal of communism as not only a political danger, but also as a danger to humanity, morality and the family:

Fascism emerged in the west on the ravages of democracy, which could not oppose Bolshevism when it wanted to invade from Russia to the west. Her system, her methods of work and the resources she could muster, could not measure and even less suppress and defy the ways of the work of Bolshevism and its means of struggle, just as a fishing boat cannot oppose a battleship. Something new, something stronger and more capable of fighting Bolshevism was needed, capable of defeating it. And this has been found in fascism. Of course, fascism first had to remove democracy, which proved to be inadequate and incompetent for that struggle. ${ }^{59}$

The period $1938-1940$ is especially interesting also from a theoretical point of view because political developments opened for the UHRO, while still being banned, to act inside Yugoslavia by proxy. Believing they could control the Ustašas, the Yugoslav government reached an agreement with Italy that

57 Miloš Zdravković, 'Ustavnopravni temelji Nezavisne Države Hrvatske,' Anali pravnog fakulteta u Beogradu 67, no. 1 (2019): 127 .

58 For more details on the fascitisation of the Ustaša organisation, see Dulić and Miljan, "The Ustašas and Fascism.'

59 Ante Pavelić, Strahote zabluda: komunizam i boljševizam u Rusiji $i$ u svijetu (Zagreb: Croatiaprojekt, 2000), 49 . 
allowed for the return of exiled Ustašas including Mile Budak to the country. The sworn-in Ustaša members immediately embarked on a propaganda and networking campaign that involved the creation of journals such as Hrvatski Narod, Hrvatska Smotra and Hrvatska Revija, all of which published articles questioning the Versailles Agreement and engaged with other contentious issues. During this period, the organisation also developed 'transnational' cooperation with several other fascist and right-wing organisations. Contacts were of course established with the Italian fascists early on, as well as with the NSDAP. Apart from that, however, the Ustašas also cooperated with some influential revolutionary nationalist organisations, such as the Organisation of Ukrainian Nationalists (OUN), while trying albeit being less successful in attracting support from various Croatian emigrant organisations in countries such as Belgium, the United States and Argentina. ${ }^{60}$ While remaining in Italy, Pavelić and the Ustaša leadership worked with its representatives inside Yugoslavia to establish alliances with nationalist individuals and organisations such as the cooperative Uzdanica and the academic society August Šenoa. ${ }^{61}$ The network is reminiscent of a movement with its organisations and networks that crossed national borders. However, it is questionable whether these entities were part of a movement that can be termed fascist in any meaningful way, or if we are dealing with a nationalist movement for Croatian independence led by a fascist organisation. Neither did the UHRO work for a 'common good' with fascist or right-wing entities in other countries, but instead focused on national independence for Croatia.

\section{Independent State of Croatia}

By the time uHRo had transformed into a fascist entity, political events once more played tricks with the prospect of Croatian statehood. After first becoming disenchanted with the Hss leadership under Vladimir Maček following the establishment of Banovina Hrvatska in 1939 and the latter's entry into the Yugoslav government, the Ustaša once again found themselves sidestepped by political developments. Even though the outbreak of the Second World War at first suggested the destruction of Yugoslavia was a matter of time, Berlin disappointed by starting negotiations with Belgrade to have Yugoslavia join the Tripartite Pact. The talks intensified in the autumn of 1940 because of the Italian debacle during the Greek campaign and culminated with Yugoslavia's

6o Jelić-Butić, Ustaše i NDH, 27-29.

61 Ibid., 43, 50. 
signing of the pact on 25 March $1941 .{ }^{62}$ Ustaša propaganda during late 1940 illustrates well the disappointment felt by the Ustaša elite. While having presented the 'maximalist' version of 'Greater Croatia' (including Montenegro, Sandžak and Bačka) as its goal through propaganda in the autumn of 1940, ${ }^{63}$ Pavelić found himself sidestepped by the new turn of events. Evidently distraught by the prospect of not being able to re-establish Croatia as an independent state anytime soon - if at all — he issued a propaganda leaflet that shows the preparedness of UHRO to compromise even on the key 'thousand years dream' of independence:

The time has come when we, the Croatian nationalists, have to speak openly. For far too long, too many of us have been uttering the liberal-democratic phrases - 'liberation', 'independence' and 'peace' .... There will be no independence until we voluntarily adapt to the science of fascism and its leaders; there will be no peace for as long as our Italian brothers are preoccupied with such a bitter struggle .... What will happen after the war? I have received a holy vow by the Duce himself, that Croatia and her services will not remain unrewarded. She will have a perfect part to play in the 'new order' as a bridge between fascist Italy and national socialist Germany .... Although borders will divide us, we will be united in a spirit of devotion to the totalitarian ideals. ${ }^{64}$

Following a coup d'état in Belgrade on 27 March 1941, a major political change occurred that had a profound effect on various levels. Because of the invasion of Yugoslavia in April 1941, the organisation became a state-founding political party endowed with control over a military, a state apparatus, an education system and various media outlets. The speed with which the new state authorities reorganised the state apparatus to mimic the fascist system of joining the party structures with governmental authorities; implementation of a 'charismatic' leadership embodied in the Poglavnik; adoption of racial laws and a concentration camp system; and efforts to educate the youth into the ideals of the 'new man' show that the UHRO had adopted fascism as a core ideology. The revolution aimed to achieve the totalitarian remoulding of the society and population and introducing a totalitarian system described in a speech by Mirko Puk, the Minister of Justice and Religion, during the meeting of the Sabor in early 1942:

62 Tomasevich, War and Revolution in Yugoslavia 1941-1945, 46.

63 Croatian State Archives, Stampata NDH (ZB-XVIII-L-29/1318).

64 Croatian State Archives, Stampata NDH (ZB-XVIII-L-29/1340). 
The authoritarian state refutes the legal theories that have existed so far, according to which all people are equal and instead adopts another principle of the selection of human beings. According to that and the spirit of the Ustaša Principles, the new legal system had to be organised according to the principles of leadership, the so-called Führer-principle ... The authoritarian state, the state of the new order, is not a despotism, a satrapy, but a state where the leader rules, as the best among the people, in cooperation with the other good and best members of a people, where in accordance with the legal form he decides after listening to them and makes his own decision. ${ }^{65}$

It should be clear from the aforementioned that there is in fact little in the Ustaša Constitution that suggests it resembled anything akin to a social or political movement, but in fact was an organisation with a clear and hierarchically organised and 'top-down' decision-making structure. The question, therefore, is whether one could view it as a part of a (nationalist) Croatian movement during the brief period it collaborated with Uzdanica and others in 1936-1940, or if it was an SMO in the framework of a European-wide fascist movement. This, it seems at first glance, is more reasonable, because within a relatively short time after the adoption of the Principles, the UHRo began a gradual process of fascistisation that was directly influenced by its relationship to Italy. In the case of Croatia, however, the UHRo leadership soon monopolised virtually all means of collective action in line with Rucht's argument.

\section{Conclusion}

As shown in the empirical analysis, the UHRO was established as a terrorist organisation in the early 193os. The Ustašas coordinated their activities with the regimes in Hungary and Italy and through VMro in Bulgaria with its ties to parts of the Bulgarian polity. The UHRO was hierarchically organised with a very strict top-down command structure that emphasised obedience until death, where the principle of charismatic authority was important. Although it initially focused on one question - the independence of Croatia - which is characteristic of social movements, the decision-making structure of UHRO is hardly reminiscent of what scholars usually mean when referring to

65 Brzopisni zapisci prvog zasjedanja Hrvatskog državnog sabora u Nezavisnoj Državi Hrvatskoj godine 1942. Od I. do XII. saborske sjednice od 23. veljače do 28. prosinca 1942 (Zagreb: Hrvatski Državni Sabor, 1942), 37-38. 
'movements'. Neither was it a movement party, but a terrorist organisation that existed mainly outside of Yugoslavia and had no access to the state polity.

Concluding that the UHRO was not a movement begs the question whether or not we can regard it as an SMO within the framework of a transnational fascist movement. The UHRO was definitively part of a web of fascist organisations that provided both ideological guidance and identified enemies against which it was fighting, including the PNF, VMRO, OUN and authorities in revanchist Hungary. This notwithstanding, one also needs to remember that some of the entities they interacted with can hardly be considered fascist. Even if removing the non-fascist entities from the would-be transnational fascist movement, one is left with the problem of identifying the counterpart with which the supposed movement is interacting in order to achieve what can be considered a reasonable 'common good' that united the different entities that made up the movement. Overall, fascist entities acted in a context dominated by the nation-state that had not yet begun to be challenged by the structural changes brought about by late twentieth-century globalisation processes. As a result, there was in fact not very much that networks of fascist entities could do to influence governments 'from above' and they by and large limited their activities to international exchange through state-based organisations such as Comitati d'Azione per l'Università di Roma (CAUR), Fasci Italiani all'Estero or the youth organisations Balilla and Gioventù italiana del Littorio all'estero. ${ }^{66}$

This serves to illustrate that efforts to study European fascism as a transnational movement runs into several theoretical problems that have hardly been addressed in comparative fascist studies. While today we speak of transnational movements that act on the 'transnational space' referred to by Guidry et al., such arenas hardly existed during the interwar period and even if they did, they would be difficult to reconcile with a fascist political ideology fundamentally opposed to 'internationalism' that would curtail sovereignty in any way. This is not to say that one cannot use the term 'transnational' in a different way to denote what essentially is international knowledge-transfer between state-based and even governmental entities. However, this type of expansion of transnationalism as a concept obscures the distinction that is often made between the type of activities 'above' or 'beyond' the state and international knowledge-transfer that had no wider goals.

66 Luca de Caprariis, “Fascism for Export'? The Rise and Eclipse of the Fasci Italiani all'Estero,' Journal of Contemporary History 35, no. 2 (2000): 151-183; Katharina Schembs, 'Fascist Youth Organizations and Propaganda in a Transnational Perspective: Balilla and Gioventù Italiana del Littorio All'estero in Argentina (1922-1955),' Amnis no. 12 (2013), https://doi.org/10.40oo/ amnis.2021. 
While these aspects point to a need for more conceptual groundwork to be done before fascism can be studied as a movement (transnational or otherwise), one also needs to keep in mind that this analysis dealt with one of many fascist entities. Social movement theory might therefore still provide a useful tool for the analysis of entities that might be more reasonably defined as movements than the UHRO. However, there are some alternatives to social movement theory, which should be considered for those seeking to understand the way in which fascist entities organise, mobilise and function from a theoretical point of view. As Diani and Bison point out, not all collective action is attributable to social movements. This is particularly true of the 'conflictual organisational processes' into which they put Nazi and Bolshevik revolutionary activities 'where actors with legitimacy to mobilise will be those who do so through organisations, and there will be few opportunities for individuals to play any role unless their participation is mediated by specific organisations' ${ }^{\prime} 7$ In a recent effort to bridge the theoretical and conceptual gap between social movement and organisation theory, Clemens furthermore draws our attention to the fact that social movement theory deals with the relationships among smos and individuals that make up movements. ${ }^{68}$ Organisation theory, by contrast, deals with relationships within organisations. Keeping this in mind, comparative analyses should pay more attention to organisation theory while also trying to better understand how at least some fascist entities that can be understood as social movements transform into political organisations (whether parties or movement parties), which will also deepen the analysis of transnational—or perhaps better international—fascism. A more precise and theoretically well-founded understanding and implementation of concepts and theory would probably also help explain the nature of fascist ideology and praxis and its transformation over time.

67 Mario Diani and Ivano Bison, 'Organizations, Coalitions, and Movements,' Theory and Society 33, no. 3/4 (2004): 286 .

68 Elisabeth S. Clemens, 'Two Kinds of Stuff: The Current Encounter of Social Movements and Organisations,' in Social Movements and Organisation Theory, ed. Gerald F. Davis et al. (New York, N.Y: Cambridge University Press, 2005). 